\title{
EDITORIAL
}

\section{The digitization of working life: Challenges and opportunities}

\author{
ANA-MARIA CAZAN \\ Transilvania University of Brasov, Romania
}

\section{Digital employees and digital organizations: Challenges and opportunities}

In recent years, the role of technology in working life has increased. Technology and digitalization play a crucial role in the development of the organizations and the entire societies. The ascendance of digital organizations has also become a widely researched topic, the digital workplace environment being an important organizational asset for increasing employee productivity (Köffer, 2015). Digitalization creates changes in the world of work, impacting not only business performance and worker productivity, but also job satisfaction, work/life balance, worker autonomy and monitoring across hierarchical levels. Information and Communication Technologies (ICT) in particular are essential components of working and important working tools (Korunka \& Vartiainen, 2017).

According to OECD (2019) nearly $14 \%$ of the current jobs could be automated, $32 \%$ employees need to learn new skills to do their jobs, major changes are needed to succeed in the new digitally enabled work environment. Human replacement by machines and technological changes are becoming main stressors and threats to employment and job existence (Nam, 2019). Besides automation, the type of knowledge, skills, and abilities required by organisations changed, autonomy, interdependence, increased cognitive, creative, technical and social skills are also necessary (Parry \& Battista, 2019). Other researchers discuss the benefits of technology at the workplace, such as the decline in workload in many work areas. Intensified autonomy demands are also increased by the expansion of ICT (Korunka \& Vartiainen, 2017) and the permanent interconnection of work positions; despite increased flexibility of time and place, developments in mobile technologies accelerated the tempo of daily life, adding the necessity to constantly be online and connected to the workplace, reduced pauses, more multitasking and more time pressures (Cijan, Jenič, Lamovšek, \& Stemberger, 2019).

The advances in information technology, the expansion of the communication apps and the availability of computer and internet access enable employees to carry out activities at remote locations, with teleworking becoming an alternative work arrangement in the developed world (Biron \& van Veldhoven, 2016). Researchers were interested in analysing the impact of teleworking arrangements on employees' social relationships, work-family conflict, job satisfaction, organisational commitment or job performance (Biron \& van Veldhoven, 2016; Groen, van Triest, Coers, \& Wtenweerde, 2018). While teleworking has the advantages of control over work location and flexibility in the location of work and in the allocation of 
time, there are also negative consequences such as social isolation, career stagnation, work-family conflict, or reduced possibilities of monitoring employee behaviour (Biron \& van Veldhoven, 2016).

\section{Digitalization, wellbeing and occupational health}

Technology and digitalization invaded nearly every aspect of our private and professional lives. Recent research discusses the associations between work-related stress, occupational safety and health and digitization. Digitalization led to greater performance demands on employees in terms of self-organization and reachability, affecting the boundaries between working time and private life. Pressures are higher than ever before because working with the Internet highlights the expectation that requests will be answered rapidly. The pressure is also augmented by the permanent necessity to keep up with the novelties which substantially increase the employees' performance pressure. These high work pressures are the causes of psychosocial health risks (Ahlers, 2016). Mobile and smart technologies brought not only flexibilization but also an increase rate of risk of accidents, injury could occur from direct contact with robots or other equipment. Increased working with technology significantly reduces the contact with human peers and social support, which could be detrimental to workers' mental health (European Agency for Safety and Health at Work, 2019).

ICT and digitalization also have positive effects, such as a more effective intraorganizational collaboration, improvement of cross-departmental communication increased productivity and satisfaction in team work related contexts; studies also showed that cultural aspects such as power distance become less dominant (Meske, Kissmer, \& Stieglitz, 2020). Digitalization is also a job resource; on the one hand, it brings greater flexibility in work scheduling and location enabling employees' control over the time and place of their work; on the other hand, digitalization decreases the physical and emotional demands through automation of the repetitive, unmotivating, and physically challenging work processes (Larjovuori, Bordi, Mäkiniemi, \& Heikkilä-Tammi, 2016). The cited authors also proposed a new concept of "techno-work engagement" as an indicator of subjective well-being in organizations.

\section{Technostress - the dark side of the technology}

Although technology is largely beneficial to employees and organizations, it can also have "dark" sides, such as technostress. Technostress is a psychological state of stress associated with IT use or IT use demands (Gaudioso, Turel, \& Galimberti, 2017). Related to work, Salanova, Llorens, \& Cifre 2013) defined the technostress experience at work as a "negative psychological state associated with the use or threat of ICT use in the future. This experience is related to feelings of anxiety, mental fatigue, scepticism and inefficacy" (p. 423). Technologies at work can be intrusive, contributing to a sense of techno-invasion and overwhelming, which lead to higher work pressures, perceptions of work overload, information fatigue, frustration, demoralization, loss of motivation, job burnout, poor job performance, intentions to quit a job and dissatisfaction at work (Tarafdar, D'Arcy, Turel, \& Gupta, 2015).

The effects of technostress are anxiety, fatigue, scepticism and inefficacy related to the use of ICT, computer anxiety being one of the most widely studied technostrain experience. Research concerning the attitudes towards the computer and the internet reported that some adults exhibit high levels of computer anxiety, experience feelings of discomfort, frustration and stress, anticipate catastrophic consequences of their errors such as hitting a wrong key and losing information (Cazan, Cocorada, \& Maican, 2016). Feeling inefficacious in the use of ICT is another component of technostrain and it refers to the perceived level of inefficacy when using ICT (Schaufeli \&Salanova, 2007). Computer selfefficacy is associated with perceptions about computers such us usefulness and ease of use, being also related to users' attitudes, 
intentions to use computers, actual computer use, computer skills and computer anxiety (Karsten, Mitra, \& Schmidt, 2012).

Researchers have also frequently studied computer anxiety and computer self-efficacy in association with dimensions of the technology acceptance model (Venkatesh, 2000), such as perceived usefulness, perceived ease of use, behavioural intention, behaviour, computer skills. In organizational settings, the technology acceptance model was related to issues such as reasons for collaboration, costs and benefits of collaboration, work group characteristics and attitude toward change (Karsten et al., 2012). Previous research showed that organizations wishing to promote the use of an IT system should provide supervisory support and enhance extensive relations among colleagues to facilitate a more favourable attitude towards the IT systems (Lee, Rhee, \& Dunham, 2009). The perceived usefulness and "cost" of new technologies could also influence their acceptance. In addition, personality traits and work engagement play an important role in technology acceptance (Lee et al., 2009), more specifically work engagement mediates the relationship between personality traits and the use of online communication and collaboration applications in the professional life (Maican, Cazan, Lixandroiu, \& Dovleac, 2019).

Another dark side of technology could be explained by the excessive and compulsive work with ICT, namely the technoaddiction. Technoaddiction is seen as a form of workaholism (Porter \& Kakabadse, 2006; Salanova et al., 2013). Thus, technoaddiction is a form of technostress experience due to an uncontrollable compulsion to use ICT for long periods of time in an excessive way (Salanova et al., 2013). As expected, higher levels of technoaddiction are associated with lower levels of wellbeing (Huang, 2010).

\section{Conclusions}

Technology and digitalisation make possible new developments in the workplace, but also brings challenges. Despite its dark sides discussed above, digitalisation can create opportunities for improving working conditions and enhancing employees' wellbeing. Technology impacts not only how our work is organized but also our work performance, nearly every aspect in the world of work being influenced by ICT (Korunka \& Hoonakker, 2014). In order to enhance the positive aspects of digitalization and to reduce its disadvantages, we should aim for attaining "digital maturity". Digital maturity is "an organization's capability to recognize and utilize the opportunities provided by the development of digital technology and the ability to carry out strategies to execute the vision" (Larjovuori et al., 2016, p. 1144).

\section{References}

Ahlers, E. (2016). Flexible and remote work in the context of digitization and occupational health. International Journal of Labour Research, 8(1-2), 85-99.

Biron, M., \& van Veldhoven, M. (2016). When control becomes a liability rather than an asset: Comparing home and office days among part-time teleworkers. Journal of Organizational Behavior, 37(8), 1317 1337. https://doi.org/10.1002/job.2106

Cazan, A.M., Cocoradă, E., \& Maican, C. I. (2016). Computer anxiety and attitudes towards the computer and the internet with Romanian high-school and university students. Computers in Human Behavior, 55, 258-267. https://doi.org/10.1016/j.chb. 2015.09.001

Cijan, A., Jenič, L., Lamovšek, A., \& Stemberger, L. (2019). How digitalization changes the workplace. Dynamic Relationships Management Journal, 8(1), 3-12.

https://doi.org/10.17708/DRMJ.2019.v08n01a01

European Agency for Safety and Health at Work. (2019). Digitalisation and occupational safety and health (OSH) An EU-OSHA research programme. Retrieved from file:///C:/Users/anamaria/Downloads/Digitalisation_and_OSH_2019.pd $\mathrm{f}$

Gaudioso, F., Turel, O., \& Galimberti, C. (2017) The mediating roles of strain facets and coping strategies in translating techno-stressors into adverse job outcomes. Computers in Human Behaviour, 69, 189196. https://doi.org/10.1016/j.chb.2016.12.041

Groen, B. A. C., van Triest, S. P., Coers, M., \& Wtenweerde, N. (2018). Managing flexible work arrangements: Teleworking and output controls. European Management Journal, 36, 727-735. https://doi.org/10.1016/j.emj.2018.01.007

Huang, C. (2010). Internet use and psychological wellbeing: A meta-analysis. CyberPsychology. Behavior, and Social Networking, 13, 241-249. https://doi.org/10.1089/cyber.2009.0217 
Karsten, R., Mitra, A., \& Schmidt, D. (2012). Computer Self-Efficacy: A Meta-Analysis. Journal of Organizational and End User Computing, 24(4), 5480. https://doi.org/10.4018/joeuc.2012100104

Köffer, S. (2015). Designing the digital workplace of the future - What scholars recommend to practitioners. Paper presented at the International Conference of Information Systems 2015, Fort Worth, TX, U.S.A.

Korunka, C., \& Hoonakker, P. (2014). The Future of ICT and Quality of Working Life: Challenges, Benefits, and Risks. In C. Korunka \& P. Hoonakker (Eds.), The Impact of ICT on Quality of Working Life (pp. 205220). New York, London: Springer.

Korunka, C. \& Vartiainen, M. (2017). Digital Technologies at Work Are Great, Aren't They? The Development of Information and Communication Technologies (ICT) and Their Relevance in the World of Work. In N. Chmiel, F. Fraccaroli, \& M. Sverke (Eds.). An Introduction to Work and Organizational Psychology (pp. 102-120), Hoboken: John Wiley \& Sons. https://doi.org/10.1002/9781119168058.ch6

Lee, D., Rhee, Y., \& Dunham, R. B. (2009). The Role of Organizational and Individual Characteristics in Technology Acceptance. International Journal of Human-Computer Interaction, 25(7), 23-646. https://doi.org/10.1080/10447310902963969

Maican, C. I., Cazan, A, M., Lixandroiu, C. R., \& Dovleac, L. (2019). A study on academic staff personality and technology acceptance: The case of communication and collaboration applications. Computers \& Education, 128, 113-131. https://doi.org/10.1016/j.compedu.2018.09.010

Meske, C., Kissmer, T., \& Stieglitz, S. (2020). Bridging formal barriers in digital work environments Investigating technology-enabled interactions across organizational hierarchies. Telematics and Informatics, 48, 1-14. https://doi.org/10.1016/j.tele.2020.101342
Nam, T. (2019). Technology usage, expected job sustainability, and perceived job insecurity. Technological Forecasting and Social Change, 138, 155-165.

https://doi.org/10.1016/j.techfore.2018.08.017

OECD (2019). Preparing for the Changing Nature of Work in the Digital Era. Retrieved from https://www.oecd.org/going-digital/changing-natureof-work-in-the-digital-era.pdf 15.03.20

Parry, E., \& Battista, V. (2019). The impact of emerging technologies on work: A review of the evidence and implications for the human resource function. Emerald Open Research, 1(5). https://doi.org/10.12688/emeraldopenres.12907.1

Porter, G., \&Kakabadse, N. K. (2006). HRM perspective on addiction to technology and work. Journal of Management Development, 25(6), 535-560. https://doi.org/10.1108/02621710610670119

Salanova, M., Llorens, S., Cifre, (2013). The dark side of technologies: Technostress among users of information and communication technologies. International Journal of Psychology, 48(3), 422-436. https://doi.org/10.1080/00207594.2012.680460

Tarafdar, M., D'Arcy, J., Turel, O., \& Gupta, A. (2015). The dark side of information technology. MIT Sloan Management Review, 56(2), 600-623.

Larjovuori, R.-L., Bordi, L., Mäkiniemi, J.-P., \& Heikkilä-Tammi, K. (2016). The role of leadership and employee well-being in organizational digitalization. In T. Russo-Spena \& C. Mele (eds.), What's ahead in service research? New perspectives for business and society (pp. 1141-1154). Proceedings of the 26th Annual RESER Conference, 8-10 September, Naples. 